\title{
Polsko-niemieckie miejsca pamięci Vol 4: Refleksje metodologiczne ed. Robert Traba, Hans Henning Hahn in cooperation with Maciej Górny, Kornelia Kończal Warszawa 2013, pp. 362
}

$\mathbf{T}$ here is no doubt that the history of Poland and Germany is joined together in a unique way. For this reason, it is difficult for Poles to understand their own history without the knowledge of the history of Germany and vice versa. Also for this reason, in the awareness of both societies shared realms of memory exist, however, they are often stored differently. The category of realms of memory has been known since the 1980s and since then went through many interpretations, but so far there was no research on Polish and German culture of memory, which would present the functioning of memory in the collective consciousness of Poles and Germans in a comprehensive and extensive manner.

The following publication is the result of the Polish-German project entitled Polish-German Realms of Memory/DeutschPolnische Erinnerungsorte (full title of the project: Polish and German Cultures of Memory in the History of Long Duration
(Longue Durée). A New Approach to the History of Polish-German Relations) implemented by the Centre for Historical Research of the Polish Academy of Sciences in Berlin (CHR PAS). The initiators of this project were Robert Traba from the Centre for Historical Research of the Polish Academy of Sciences in Berlin (CHR PAS) and Freie Universität Berlin, Friedrich Meinecke Institut and Hans Henning Hahn from Oldenburg University. Both Professor Robert Traba and Professor Hans Henning Hahn are the authors of several articles and monographs as well as the editors of works dedicated to the study of the collective cultural memory and PolishGerman relations. As in previous publications published as part of this project, they collaborated with Kornelia Kończal from CHR PAS and Maciej Górny from the Institute of History of the Polish Academy of Sciences.

The project was implemented in the period from 2006 to 2011 and its aim was to 
study and present - in the form of a fourvolume publication - Polish and German culture of memory in a wide temporal and spatial perspective. All articles collected in these publications are devoted to realms of memory, the category proposed in the 1980s by Pierre Nora (lieu de memoire). Places of memory are understood here as events, people, and other historical phenomena, which both determine and reflect the formation of collective identities.

The whole series consists of four parts. The first and second volumes entitled Joint/separate are devoted to the realms of memory that are common to both communities - Polish and German - but often occurring in a confrontational way to each other. The third volume Parallels presents the realms of memory similar to each other in terms of functionality. The authors present a dozen realms of memory, such as Beethoven/Chopin, Goethe/Mickiewicz, Wisła/Ren and try to answer the questions: why specific realms of memory have become part of the collective identity and which realms of memory have similar functions in the neighboring culture?

Polsko-niemieckie miejsca pamięci, Vol 4: Refleksje metodologiczne is a collection of 24 articles divided into three parts. The editors consider them to be comments to previous volumes published rather than their continuation. This is the last of the parts published in Poland, ending the series and summarizing the project. In Germany the fifth part with selected articles of Polish authors translated into German will be released later.

Authors of articles posted in this work are researchers from Germany, Poland, Czech Republic, Austria, Italy and Switzerland, who represent various humanities and social sciences, with rich scientific achievements related to research on cultural memory. This volume focuses mainly on comparison of Polish and German concepts of cultures of memory and combines them with global research on realms of memory. The intention of the authors was to present the methodological assumptions on which the research project and the articles contained in the previously published volumes were based.

The first part of book titled: Polskoniemieckie miejsca pamięci $w$ międzynarodowym $i$ interdyscyplinarnym kontekście (Polish-German realms of memory in an international and interdisciplinary context) is a collection of five essays that were devoted to the transnational history and transnational memory, which are currently the focus of the methodological discussion of historiography.

The authors of this section argue that in the study of realms of memory and cultures of memory it becomes important not to receive national history but transnational history. Michael G. Müller appealed to new theoretical and methodological concepts such as histoire croisée, entangled history or comparativist theories. The focus of this current historical research is the processes of cultural transfer and links between phenomena and actors operating in different contexts - local, regional or national.

Moritz Csáky in his article argued that the culture as a space of communication is always a "hybrid conglomerate" and history becomes ambiguous in the sense of histoire croisée, which means that, for a given collective, historical experience does not have a binding memory and one binding historical narrative. Martin Aust presented the possibility of a comparative study of the Polish historical memory, for example, the Catholic messianic significance for the formation of the nation in 
the nineteenth and twentieth century (in comparison with Ireland). He also showed examples of research on the history of interactions, such as the memory of the Battle of Grunwald, the history of expulsions and deportations, etc. Heinz Duchhardt and Étienne François presented the perspective of research on European realms of memory and problems which researchers may encounter studying the European memory.

In the second part, entitled: Metodologiczne spory wokót badań nad pamięcia zbiorowa (Methodological disputes over research on collective memory) contains eight articles devoted to various research approaches to the realms of memory. Kornelia Kończal presented the development of research on the category of realms of memory in selected European countries, among others, France, Germany or Belgium. Hubert Orlowski appealed to the long-lived stereotype of polnische Wirtschaft and argued that it should be taken into account in the study of realms of memory. Article Christian Gudehus and Harald Welzer brought to the reader the essence of research on cultural transmission, in which the importance of linguistic and cultural conventions on collective perception of the past is emphasized. Heidi Hein-Kircher presented the influence of political myths on the culture of memory and the fluid border between these two fields of research.

Andreas Lawaty devoted his article to the analysis of the category of "remembering and forgetting". As he stated, though it is difficult to "remember together" it is even more difficult to "forget together". Hans Henning Hahn referred to the historical politics and cross-border politics of memory and he explained how the first one works in a state and how the latter, al- though present, is difficult to explore and extract.

The article of Jerzy Jedlicki is a sketch of Polish memory of communism, which points out that although every individual has its own memory of events in which he participated or was an eyewitness, ultimately what is remembered as "good and bad" is the result of political procedures. The last article in this section, by Georg Kreis, presents interpretations of the role of Switzerland in World War II and the impact of revising work on the collective awareness.

Last, the third part of the publication entitled: Pamięć a nauka (Memory and science) shows the effects and relations of selected areas of study on the formation of communities of memory. Researchers - Maciej Górny, Anna Zalewska, Tobias Weger, Joanna Wawrzyniak, Izabela Surynt, Beate Störtkuhl, Rüdiger Ritter, Peter Steinbach, Urte Kocka, and Violetta Julkowska - discussed the impact of historiography, archeology, sociology, ethnology, literary studies, art history, musicology, and science on race and teaching history.

While discussing this paper, one should pay attention to the thoughtful selection of articles that not only provide insight into the formation and progress of the project Polish-German Realms of Memory but also presents research from different areas of science that are studying the category of realms of memory and cultural memory.

The whole series has a significant educational value to researchers of politics of memory, or more broadly, cultural memory, and for people who are interested in similarities and differences in the perception of specific realms of memory. Research on realms of memory has been 
conducted for several decades, but in these four volumes specific realms of memory in the collective consciousness were presented for the first time and then also compared and correlated with the collective memory of neighbors. Although many publications have been devoted to research on cultural memory, it can be definitely said that the book Polsko-niemieckie miejsca pamięci, Vol 4: Refleksje metodologiczne deserves a special mention and it is an important contribution in the field of research on realms of memory. 